\title{
ע Työterveysyhteistyö 2000-luvulla -kirjallisuuskatsaus suomalaisista julkaisuista
}

Työterveysyhteistyöllä tarkoitetaan työnantajan, työntekijöiden ja työterveyshuollon suunnitelmallista ja tavoitteellista yhteistyötä työntekijän työhyvinvoinnin tukemiseksi. Tämän artikkelin tavoitteena on tarkastella työterveysyhteistyöhön liittyvää suomalaista kirjallisuutta, joka on julkaistu ajanjaksolla I/2000-9/2017. Kirjallisuuskatsauksessa haettiin vastauksia seuraaviin kysymyksiin: I. Mistä muodostuu toimiva työterveysyhteistyö? 2. Minkä kontekstien näkökulmista työterveysyhteistyöstä on tutkittu ja ketkä ovat tiedonantajina? 3. Millä menetelmillä työterveysyhteistyötä on tutkittu? Kirjallisuuskatsaus on kuvaileva ja integroiva. Julkaisuja haettiin useista tietokannoista (Medic, Arto, Melinda), julkaisuiden lähdeviitteistä sekä asiantuntijoiden kautta. Katsaukseen hyväksyttiin tieteelliset (I2) ja vertaisarvioimattomat (32) tutkimukset, joten analysoitava aineisto muodostui 44 julkaisusta. Kirjallisuuskatsauksen mukaan I) toimiva työterveysyhteistyö on tavoitteellista ja se perustuu työpaikan tarpeisiin. Työterveysyhteistyöllä työterveystoiminnan tulisi kiinnittyä osaksi työpaikan strategiaa ja toimintaa. Toimivan työterveysyhteistyön edellytyksenä on säännöllinen, aktïvinen ja luottamuksellinen vuorovaikutus sekä sovitut roolit ja vastuut. 2) Työterveysyhteistyötä oli tutkittu yhteistyön, työterveyshuollon ja työpaikan näkökulmista. Julkaisuissa käsiteltiin yhteistyökäytäntöjen arviointia, kehittämistä sekä yhteistyön sujuvuuteen liittyvien tekijöiden kuvaamista. Työterveyshuollon näkökulmasta käsiteltiin pääosin työterveyshuollon toiminnan arviointia ja työterveysyhteistyön kehittämistä osana työterveyshuollon prosesseja. Työpaikan näkökulmasta kuvattiïn työpaikan odotuksia ja kokemuksia yhteistyöstä. 3) Tutkimusmenetelmät olivat pääosin laadullisia sekä monimenetelmällisiä. Katsaus osoittaa, että toimiva työterveysyhteistyö perustuu yleisiin yhteistyöhön liittyviin tekijöihin. Tieteellisten tutkimusten vähäinen määrä ja kuvaileva ote osoittavat, että tarvitaan lisätietoa siitä, mistä toimiva työterveysyhteistyö koostuu.

ASIASANAT: työpaikka, työterveyshuolto, yhteistyö

SANNA PESONEN, HANNA HAKULINEN, JAANA I HALONEN

\section{YDINASIAT}

- Työterveysyhteistyö on työantajan, työntekijöiden ja työterveyshuollon suunnitelmallista ja tavoitteellista yhteistyötä.

- Työterveysyhteistyö on tunnistettu yhdeksi keskeiseksi tekijäksi vaikuttavassa työterveystoiminnassa, mutta aiheesta ei ole koottua tietoa Suomessa.
- Kirjallisuuskatsaus osoitti, että toimiva työterveysyhteistyö koostuu yhteisestä toiminnan suunnittelusta, aktiivisesta ja luottamuksellisesta vuorovaikutuksesta ja sovituista rooleista.

- Työterveysyhteistyön monitasoisuus sekä tieteellisten tutkimusten vähäinen määrä osoittivat, että tarvitaan lisätietoa toimivasta työterveysyhteistyöstä. 


\section{JOHDANTO}

Suomen väestön ikääntyminen lisää kestävyysvajetta ja tarvetta työurien pidentämiseen. Yksi keino työurien pidentämiseen on työpaikan ja työterveyshuollon välisen yhteistyön lisääminen (1). Systemaattisella yhteistyöllä tavoitellaan entistä vaikuttavampaa työterveyshuoltoa (2), mikä puolestaan voi johtaa suurempaan työhön osallistumiseen väestötasolla. Työelämän vaatimukset ovat muuttuneet 2000-luvulle tultaessa. Myös psykososiaalisten kuormitustekijöiden lisääntyminen, epävarmat työsuhteet, työkyky- ja terveyserojen polarisoituminen sekä työterveyshuollon digitalisoituminen tuovat uusia haasteita työpaikkojen ja työterveyshuoltojen väliselle yhteistyölle (3-5).

Yhteistyön käsitettä on tutkittu monilla eri tieteenaloilla (mm. liiketalous, kasvatustiede, yhteiskuntatiede). Yhteistyö on käsitteenä laaja ja monella tapaa ymmärretty. Aira (6) määrittelee toimivan yhteistyön tavoitteelliseksi ja yhdessä sovituksi. Lewisin (7) tekemän yhteistyökäsite -synteesin mukaan yhteistyö on aktiivista toimintaa, joka tapahtuu yhdessä ja tasapuolisesti. Se on myös prosessi, johon osallistuminen on vapaaehtoista ja epämuodollista. Yhteistyöllä on lisäksi monia lähikäsitteitä. Yhteistoiminnalla tarkoitetaan prosessia, jossa yksilö, ryhmät ja/ tai yhteisöt muodostavat vuorovaikutussuhteita molemminpuolisen hyödyn saavuttamiseksi (8). Koordinaatio on toimintaa, jossa erilliset yhteistyöhön liittyvät osat yhdistetään mahdollisimman tehokkaan toiminnan ja laadukkaan tuloksen saavuttamiseksi (7). Kumppanuudella tarkoitetaan organisaatioiden tai yksilöiden välistä liittoumaa, jonka avulla pyritään hallitsemaan tärkeitä strategisia haasteita $(9,10)$.

Yhteistyötä voidaan tutkia tarkastelemalla toimijoiden välistä yhteistyötä, organisaatioiden välille muodostuneita yhteistyörakenteita (11) tai -prosesseja (12). Yhteistyön rakenteellisiin edellytyksiin kuuluvat muun muassa tavoitteiden ja roolien selkeys, luottamus ja osapuolten sitoutuminen $(13,14)$, kun taas yhteistyöprosessissa tarkastellaan ihmisten käyttäytymistä $(7,15)$. Yhteistyötä kuvaavia prosessimalleja on erilaisia (16-19), joille on yhteistä yhteistyön kehittyminen vähäisestä kiinteämpään. Himmelmanin (20) neliportaisessa mallissa vähäisin yhteistyötaso (networking) perustuu tiedon vaihtamiseen. Koordinoidussa toiminnassa (coordination) yhteistyön osapuolilla on yhteiset tehtävät ja yhteensopivat tavoitteet. Kolmannella tasolla (cooperation) yhteistyön osapuolilla on yhteen sovitetut strategiat ja yhteinen tavoite. Kiinteimmässä yhteistyössä (collaboration) osapuolilla on yhteinen toimintarakenne ja -kulttuuri.

\section{TYÖPAIKAN JA TYÖTERVEYSHUOLLON VÄLINEN YHTEISTYÖ}

Suomessa työssäkäyvien terveydenhoidossa yhteistyö on ollut esillä 1950-luvulta lähtien. Aluksi yhteistyö nähtiin lääkärin ja työpaikan johdon välisenä toimintana, eivätkä työntekijät olleet siinä mukana (21). Yhteistyö näkyy 80-luvun kirjallisuudessa yhteisenä suunnitteluna (22), kun taas 90-luvulla työterveyshuollon uudeksi lakisääteiseksi tehtäväksi asetettiin osallistuminen työkykyä ylläpitävään toimintaan (23). 2000-luvulla yhteistyö nähtiin jo välttämättömänä työterveyshuollon vaikuttavuuden aikaansaamiseksi $(5,24)$. Yhteistyötä työnantajan, työntekijöiden ja työterveyshuollon välillä korostettiin myös 2000-luvun alun työturvallisuutta ja - terveyttä koskevassa lainsäädännössä (25).

Työterveysyhteistyö määriteltiin asetuksessa hyvästä työterveyshuoltokäytännöstä (26) vuonna 2014. Työterveysyhteistyöllä tarkoitetaan työnantajan, työntekijöiden ja työterveyshuollon suunnitelmallista ja tavoitteellista yhteistyötä $(24,27)$ työterveyshuoltolain toteuttamiseksi. Yhteistyön tulisi perustua työpaikan tarpeisiin ja näkyä työpaikkojen arjessa kaikilla organisaatiotasoilla ja erilaisten toimintojen yhteydessä. Yhteistyön tavoitteena on vaikuttava toiminta työn, työolojen, terveyden sekä työ- ja toimintakyvyn edistämiseksi (28).

Työterveysyhteistyön toimivuudesta on tehty kansainvälinen kirjallisuuskatsaus 2000-luvun tutkimuksista (29). Tutkimusten määrä oli vähäinen. Katsauksen tuloksien mukaan toimivassa työterveysyhteistyössä korostuvat aikaan ja paikkaan, vuorovaikutukseen ja rooleihin liittyvät tekijät. Aikaan ja paikkaan liittyvinä tekijöinä nousivat esille joustavuus, fyysinen läheisyys ja pitkäaikainen yhteistyö. Vuorovaikutukseen liitettiin yhteinen tavoite, dialogi, säännöllinen yhteydenpitäminen ja luottamus. Rooleissa korostuivat työterveyshuollon asiantuntemus sekä selkeät roolit yhteistyössä $(5,27,30-33)$.

Suomalainen työterveyshuolto on ainutlaatuinen (34). Esimerkiksi Euroopan maissa työterveyshuollon palvelujen, työterveyshuoltoon liittyvien lakien, työterveyshuollon toimijoiden koulutuksen ja työterveyshuollon seuranta- ja 


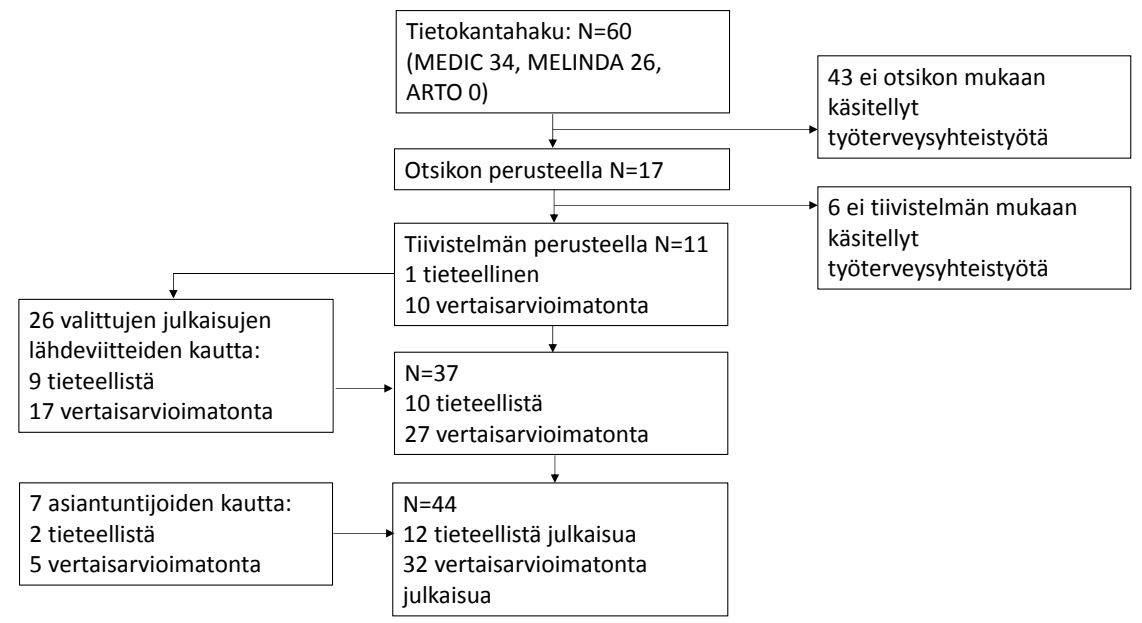

Kuva 1: aineiston haku ja valinta

ohjausjärjestelmien välillä on suurta vaihtelua (35). Siitä, miten, millä tutkimusmenetelmillä ja mistä näkökulmista työterveysyhteistyötä on Suomessa tutkittu, ei ole koottua tietoa. Tämän kirjallisuuskatsauksen tavoitteena on analysoida, millaista työterveysyhteistyö on 2000-luvun suomalaisen kirjallisuuden mukaan, jolloin työterveyshuollon ja työpaikan välisestä yhteistyöstä säädetyt lait ovat olleet voimassa (25).

Katsauksessa haettiin vastausta seuraaviin kysymyksiin: 1. Mistä muodostuu toimiva työterveysyhteistyö? 2. Minkä kontekstien näkökulmista työterveysyhteistyötä on tutkittu ja ketkä ovat tiedonantajina? 3. Millä menetelmillä työterveysyhteistyötä on tutkittu?

Kokonaiskuvan saamiseksi ja työterveysyhteistyöhön liittyvän vähäisen tutkimuksen vuoksi, katsaukseen hyväksyttiin niin tieteelliset kuin vertaisarvioimattomat julkaisut. Katsauksessa käsitellään ensisijaisesti tieteellisten julkaisujen tuloksia, joita täydennetään vertaisarvioimattomien julkaisujen tiedoilla. Saatua tietoa voidaan soveltaa työterveyshuollon kehittämisessä sekä työterveyshuollon tutkimuksen suuntaamisessa.

\section{AINEISTON KERUU JA ANALYSOINTI}

Kirjallisuuskatsaus on kuvaileva, mikä mahdollistaa laajan kuvan saamiseen työterveysyhteistyöstä (36). Kuvailevaa kirjallisuuskatsausta voidaan luonnehtia yleiskatsauksesi, ilman tiukkoja rajoja ja sääntöjä. Kirjallisuuskatsauksessa käytettävät aineistot voivat olla laajoja, eivätkä metodiset säännöt rajoita aineiston valintaa (37). Kuvaileva menetelmä sopii tähän katsaukseen, sillä työterveysyhteistyö on ilmiönä ja käsitteenä monimut- kainen (6). Tässä katsauksessa on käytetty vertaisarvioitujen julkaisujen vähyyden vuoksi myös vertaisarvioimattomia julkaisuja eri metodein tehdyistä tutkimuksista (38). Käytimme kuvailevan kirjallisuuskatsauksen alatyyppinä integroivaa kirjallisuuskatsausta, jonka tehtävänä on kuvata sen hetkistä aihealueen tutkimuksen tilaa (38). Kirjallisuuskatsaus sisälsi seuraavat vaiheet: tutkimuskysymyksen muodostaminen, aineiston valitseminen, aineiston kuvailu ja tulosten tarkasteleminen (39).

Tässä katsauksessa aineistoa haettiin suomalaisista tietokannoista (Medic, Arto, Melinda). Hakusanoina olivat: yhteist* JA työterveys* JA työpaikka*. Ajallinen rajaus tehtiin aikavälille tammikuu 2000 - syyskuu 2017, koska haluttiin saada tietoa siitä, miten työterveysyhteistyötä on tutkittu sen jälkeen, kun yhteistyöstä työterveyshuollon ja työpaikan välille säädettiin lailla 2000-luvun alussa. Analysoitavaksi hyväksyttiin suomenkieliset työterveyshuollon ja työpaikan välistä yhteistyötä käsittelevää empiiristä tutkimusta raportoivat julkaisut. Edellä kuvatuilla hakumenetelmillä löytyi yhteensä 60 julkaisua. Aluksi tietokannoista etsittiin vertaisarvioituja julkaisuja, mutta niiden vähyyden vuoksi päätimme laajentaa hakua vertaisarvioimattomiin julkaisuihin (opinnäytetyöt, vertaisarvioimattomat artikkelit, selvitykset ja hankeraportit). Tämän jälkeen kävimme julkaisujen lähdeluettelot läpi sekä pyysimme työterveyshuollon kehittäjiä ja tutkijoita täydentämään kirjallisuutta. Lopullinen aineisto muodostui 44:stä julkaisusta, joista 12 oli tieteellisiä vertaisarvioituja ja 32 vertaisarvioimattomia (Kuva 1). Taulukko katsaukseen valituista julkaisuista on liitteenä. 
Aineisto ryhmiteltiin taulukkoon (saatavissa kirjoittajilta) tutkimuskysymyksittäin: nimi, tekijä/t ja teoksen keskeinen sisältö ja lähestymistapa, tutkimus- ja aineistonkeruumenetelmä/t, tiedonantajat sekä tutkimuksen päätulokset. Aineistosta pelkistettiin toimivaa työterveysyhteistyötä kuvaavia edistäviä ja estäviä ilmaisuja. Analyysiyksikkönä oli julkaisu. Toimivan yhteistyön kuvaukset ryhmiteltiin induktiivisesti kolmeen yläluokkaan: suunnitelmallinen toiminta, toimiva vuorovaikutus ja työterveyshuoltoon ja työpaikkaan liittyvät edellytykset $(40,41)$. Luokat muodostuivat yhdistelemällä ja vertailemalla kuvauksien samankaltaisuuksia ja erovaisuuksia ja ne nimettiin sisältöä kuvaavilla nimillä (42). Laadullisen analyysin lisäksi käytettiin kvantifiointia, jotta saatiin esille tyypillisimmät näkemykset ja tutkimustulokset (43). Aineisto jaettiin kontekstien näkökulmien mukaan kolmeen yläluokkaan: työterveyshuollon toiminta, työpaikan toiminta ja yhteistyö. Lisäksi aineisto ryhmiteltiin tutki- musmenetelmien mukaan erillisiin taulukoihin tutkimuskysymyksien mukaisesti.

\section{TULOKSET}

Suurin osa 44:stä julkaisusta oli hankeraportteja $(17 \mathrm{kpl})$, toiseksi eniten oli tieteellisiä julkaisuja (12 kpl), opinnäytetöitä oli yhdeksän ja ammattilehtien artikkeleita kuusi. Katsauksessa käsitellään ensisijaisesti tieteellisten julkaisujen tuloksia, joita on täydennetty vertaisarvioimattomien julkaisujen tuloksilla.

\section{MISTÄ MUODOSTUU TOIMIVA TYÖTERVEYSYHTEISTYÖ?}

Työterveysyhteistyön sisältö jaettiin kolmeen yläluokkaan: 1) suunnitelmallinen toiminta, 2) toimiva vuorovaikutus ja 3) työterveyshuollon ja työpaikan toimijoihin liittyvät edellytykset (Taulukko 1). Tulososion viitteiden numeroinnissa viitataan katsaukseen valittujen artikkelien liitetaulukkoon ( $\mathrm{tj}=$ tieteellinen julkaisu, va=vertaisarvioimaton julkaisu).

Taulukko 1. Toimivan työterveysyhteistyön edellytykset tieteellisissä ja vertaisarvioimattomissa julkaisuissa; mainintojen lukumäärät ja osuudet tieteellisistä tai vertaisarvioimattomista julkaisuista.

\begin{tabular}{|c|c|c|c|}
\hline Yläluokka & Alaluokka & $\begin{array}{c}\text { Tieteelliset julkaisut, } \\
\operatorname{lkm}(\%)\end{array}$ & $\begin{array}{c}\text { Vertaisarvioimattomat } \\
\text { julkaisut, } 1 \mathrm{~km}(\%)\end{array}$ \\
\hline \multirow[t]{7}{*}{$\begin{array}{l}\text { Suunnitelmallinen } \\
\text { toiminta }\end{array}$} & $\begin{array}{l}\text { Työterveyshuollon (tth) } \\
\text { palvelujen tarpeenmukaisuus }\end{array}$ & $8(67)$ & $12(38)$ \\
\hline & $\begin{array}{l}\text { tth:n toiminnan kiinnittäminen } \\
\text { osaksi työpaikan toimintaa }\end{array}$ & $4(33)$ & $12(38)$ \\
\hline & $\begin{array}{l}\text { yhteinen toiminnan suunnittelu, } \\
\text { seuranta ja arviointi }\end{array}$ & $4(33)$ & $17(53)$ \\
\hline & yhteiset toimintamallit & $3(25)$ & $9 \quad(28)$ \\
\hline & pitkäjänteisyys, jatkuvuus & $4(33)$ & $8 \quad(25)$ \\
\hline & yhteinen tavoite & $4(33)$ & $10(31)$ \\
\hline & ennakoiva toiminta & $1(8)$ & $5 \quad(16)$ \\
\hline \multirow[t]{6}{*}{ Toimiva vuorovaikutus } & aktiivinen vuorovaikutus & $4(33)$ & $18(56)$ \\
\hline & motivaatio ja sitoutuminen & $3(25)$ & $11(34)$ \\
\hline & sujuva tiedonkulku & $2(17)$ & $13(41)$ \\
\hline & yhteistyön säännöllisyys & $2(17)$ & $10(31)$ \\
\hline & luottamus yhteistyössä & $1(8)$ & $7 \quad(22)$ \\
\hline & yhteinen terminologia & $2(17)$ & $2(6)$ \\
\hline \multirow{6}{*}{$\begin{array}{l}\text { Työterveyshuollon ja } \\
\text { työpaikan toimijoihin } \\
\text { liittyvät edellytykset } \\
\text { työterveysyhteistyössä }\end{array}$} & selkeät roolit ja vastuut & $6(50)$ & $10(31)$ \\
\hline & tth:n palvelujen saatavuus & - & $14(44)$ \\
\hline & tth tuntee työpaikan toiminnan & $4(33)$ & $8 \quad(25)$ \\
\hline & $\begin{array}{l}\text { riittävä osaaminen ja } \\
\text { asiantuntemus }\end{array}$ & $3(25)$ & $9 \quad(28)$ \\
\hline & Työpaikka tuntee tth:n toiminnan & $3(25)$ & $7 \quad(22)$ \\
\hline & tth:n puolueettomuus & $1(8)$ & $6 \quad(19)$ \\
\hline
\end{tabular}




\section{Suunnitelmallinen toiminta}

Lähes kaikissa tieteellisissä julkaisuissa toimivan yhteistyön perustaksi mainittiin työpaikan tarpeisiin perustuvat työterveyspalvelut ( $\mathrm{tj} 1,3,5-9$, 12,). Yhteistyö edellytti myös yhteistä tavoitteen asettamista, toiminnan suunnittelua, seurantaa $j a$ arviointia (tj 3-5, 7, 12). Yhteistyön tavoitteena oli strateginen kumppanuus, jossa työterveyshuollon toiminta on osa työpaikan strategiaa ja toimintaprosesseja (tj 3, 6, 10, 12). Lisäksi yhteistyö edellytti sitoutumista yhteisiin toimintatapoihin (tj 11), toimivia yhteistyörakenteita (tj 1) ja yhteisiä prosesseja (tj 2). Pitkäjänteinen yhteistyö nähtiin edellytyksenä kumppanuusyhteistyölle ja yrityksen tilanteen syvälliselle ymmärrykselle ( $\mathrm{tj}$ 3, $5,7,12)$. Yhdessä tutkimuksessa yhteistyö nähtiin ennakoivana, niin, että sairaslähtöisyydestä oli siirrytty preventioon (tj 3 ).

Vertaisarvioimattomat julkaisut vahvistivat tieteellisten julkaisujen tuottamaa tietoa. Vertaisarvioimattomissa julkaisuissa korostui kuitenkin toiminnan suunnittelu, seuranta ja arviointi vahvemmin kuin tieteellisissä julkaisuissa.

\section{Toimiva vuorovaikutus}

Vuorovaikutukselta odotettiin molemminpuolista aktiivisuutta (tj 2, 3, 6, 8) ja sujuvaa tiedonkulkua ( $\mathrm{tj}$ 3, 12). Toimivassa vuorovaikutuksessa korostui myös yhteistyön säännöllisyys ( $\mathrm{tj} 11$, 12), molempien osapuolien sitoutuminen ja motivaatio yhteistyöhön (tj 3, 7,11) sekä luottamus (tj 7). Lisäksi vuorovaikutus edellytti ymmärrystä toisen osapuolen käyttämästä terminologiasta ( $\mathrm{tj}$ 1, 2). Vertaisarvioimattomissa julkaisuissa korostui tieteellisten julkaisujen tavoin molemminpuolinen aktiivinen vuorovaikutus.
Työterveyshuollon ja työpaikan toimijoihin liittyvät yhteistyön edellytykset

Työterveysyhteistyössä pidettiin tärkeänä selviä rooleja ja vastuita (tj 1, 3, 4, 6, 7, 12). Yhteistyön edellytyksenä oli, että työterveyshuolto tunsi työpaikan henkilöstön ja työympäristön ( $\mathrm{tj}$ 3, 7, 10, 12). Yhtenä keinona tähän nähtiin työterveyshuollon jalkautuminen työpaikoille (tj 2, 3). Myös työpaikan oli tunnettava työterveyshuollon toiminta, jotta se pystyi hahmottamaan työterveyshuollon tarjoamat mahdollisuudet (tj 1, 2, 7). Yhteistyön edellytyksenä oli myös työterveyshuollon laaja-alainen ja monitieteinen osaaminen (tj 3,4) sekä kyky toimia yhteistyöverkostoissa (tj 6).

Vertaisarvioimattomissa julkaisuissa tuli lisäksi esille, että työpaikalla tulisi olla riittävästi osaamista toimintasuunnitelman laatimiseen, terveysasioihin ja hyvään henkilöstöjohtamiseen liittyen (va 13, 22, 32). Lisäksi työpaikat odottivat työterveyshuollolta tarpeisiin nähden riittäviä resursseja, helppoa tavoitettavuutta ja läheistä sijaintia (va 13, 15, 16, 22, 26, 31-34, $36,37,39,43)$.

\section{TYÖTERVEYSYHTEISTYÖN JULKAISUT ERI KONTEKSTIEN NÄKÖKULMISTA JA TIEDONANTAJARYHMÄT}

Työterveysyhteistyötä oli lähestytty työpaikan, työterveyshuollon sekä yhteistyön kontekstien näkökulmista. Tieteellisissä julkaisuissa työterveysyhteistyötä oli lähestytty eniten yhteistyön ja työterveyshuollon näkökulmista. Vertaisarvioimattomissa julkaisuissa näkökulma oli usein yhteistyössä (Taulukko 2).

Taulukko 2. Tutkimuksissa esiintyneet työterveysyhteistyön kontekstien näkökulmat. Tutkittujen aihepiirien mainintojen lukumäärät ja osuudet tieteellisistä tai vertaisarvioimattomista julkaisuista.

\begin{tabular}{llcc}
\hline Näkökulma & Alaluokka & $\begin{array}{c}\text { Tieteelliset } \\
\text { julkaisut, } \mathbf{k m} \\
(\mathbf{\%})\end{array}$ & $\begin{array}{c}\text { Vertaisarvioimattomat } \\
\text { julkaisut, lkm } \\
(\%)\end{array}$ \\
\hline Yhteistyö & yhteistyökäytänteiden kehittäminen & $1(8)$ & $3(9)$ \\
& yhteistyökäytäntöjen arviointi & $2(17)$ & $3(9)$ \\
& yhteistyön tekijät & - & $6(19)$ \\
& asiakkuus & $1(8)$ & $2(6)$ \\
& vaikuttavuus ja laatu & - & $1(3)$ \\
\hline Työterveyshuolto & työterveyshuollon toiminnan arviointi & $4(33)$ & $5(16)$ \\
& uuden toimintatavan kehittäminen & $2(17)$ & $2(6)$ \\
\hline Työpaikka & strateginen kumppanuus & $2(17)$ & $2(6)$ \\
& asiakkuus & - & $4(13)$ \\
& uuden toimintatavan kehittäminen & - & $2(6)$ \\
& toimintamallin arviointi & - & $2(6)$ \\
\hline
\end{tabular}




\section{Yhteistyön näkökulma}

Tieteellisissä julkaisuissa yhteistyön arviointia oli tehty kuntoutukseen liittyen (tj 5, 12) ja yhdessä tutkimuksessa oli kehitetty yhteistyömenetelmä, jonka avulla voitiin analysoida työterveyshuollon sopimusneuvottelun etenemistä ja neuvottelun tuloksena syntyvää yhteistyötä (tj 11). Asiakkuutta oli tutkittu niin työterveyshuollon kuin työpaikan näkökulmista (tj 1).

Vertaisarvioimattomissa julkaisuissa korostui yhteistyön näkökulma. Näissä selvitettiin yhteistyön sujuvuutta (va 13), yhteistyötä estäviä ja edistäviä tekijöitä sekä kehittämistarpeita (va 37) ja eri osapuolten kokemuksia yhteistyöstä (va 36, 35). Yhteistyökäytänteiden kehittämistä oli tehty työpaikkaselvityksiin (va 26) sekä työpaikan ja työterveyshuollon yhteiskehittämismenetelmään liittyen (va 27). Yhteistyön selkeyttämiseen oli pienille työpaikoille luotu työkyvyn tukemiseen työterveyshuollon ja työpaikan työnjakoa ja vastuita kuvaava matriisi (va 16). Yhteistyömenetelmien arviointia oli tehty työterveyshuollon toimintasuunnitelmaan (va 19), työpaikkaselvitykseen ja riskinarvioinnin vaikuttavuuteen (va 25) sekä lakimuutoksiin (va 18) liittyen. Asiakkuuteen liittyen oli tutkittu sen keskeisiä tekijöitä (va 32) ja prosessimaista kehittymistä (va 39). Vaikuttavuuden ja laadun mittaamiseen oli kehitetty työkyvynhallinnan, seurannan ja varhaisen tuen indikaattorit (va 28).

Yhteistyön näkökulmasta sekä tieteellisissä että vertaisarvioimattomissa tutkimuksissa kaikissa oli tiedonantajina sekä työterveyshuollon että työpaikan edustajia. Työterveyshuollosta tiedonantajina olivat työterveyslääkärit, työterveyshoitajat ja työfysioterapeutit ja työpaikalta henkilöstöhallinto, johto, esimiehet, työsuojelu ja työntekijät.

\section{Työterveyshuollon näkökulma}

Tieteellisissä julkaisuissa työterveyshuollon menetelmien kehittämisen subteen oli arvioitu muuttuvan työelämän tuomia haasteita $(\mathrm{tj} 6,4)$ sekä kehitetty menetelmä työterveyshuollon työn ja toiminnan muutosten tunnistamiseen (tj 8). Yhdessä tutkimuksessa arvioitiin työterveyshuollon välineitä suhteessa työpaikalla tapahtuneiden muutosten tunnistamiseen (tj 9). Työterveyshuollon toimintaa kehitettiin tuottamalla tietoa työpaikkojen toiminnasta ja muutoksista työterveys- huollon toiminnan lähtökohdaksi ja yhteisen ymmärryksen pohjaksi (tj 10) sekä jäsentämällä työterveyshuollon roolia työyhteisön toimivuuden edistämisessä ( $\mathrm{tj}$ 7).

Vertaisarvioimattomissa julkaisuissa työterveyshuollon toiminnan kehittäminen koski työterveyshuollon prosesseja, joissa yhteistyö oli yhtenä kehittämisen alueena. Työterveyshuoltoon oli kehitetty osaamisverkostoa ja työterveyshuollon hyviä käytäntöjä (va 15, 14). Myös työpaikkaselvityksen (va 44) ja terveystarkastusten kehittämistarpeita oli tutkittu (va 20). Työterveyshuollon toimintaa oli arvioitu, palvelujärjestelmän toimivuuden (va 24) ja kehittämisjännitteiden näkökulmista (va 23). Myös työterveyshuollon viestinnän vaikuttavuutta oli arvioitu (va 21).

Työterveyshuollon näkökulmasta sekä tieteellisissä että vertaisarvioimattomissa tutkimuksissa oli tiedonantajina työterveyshuollon, mutta myös työpaikan edustajia. Tiedonantajina olivat työterveyshuollosta työterveyslääkärit, työterveyshoitajat, työfysioterapeutit ja työterveyspsykologit ja työpaikalta henkilöstöhallinto, johto, esimiehet, työsuojelu ja työntekijät.

\section{Työpaikan näkökulma}

Tieteellisistä julkaisuista kaksi oli tehty työpaikan näkökulmasta. Toinen tutki yhteistyötä henkilöstöriskien hallinnassa strategisena kumppanuute$n a$ (tj 2) ja toinen selvitti työpaikan näkemyksiä kumppanuusyhteistyöstä (tj 3).

Vertaisarvioimattomissa julkaisuissa työpaikan näkökulma liittyi usein asiakkuuteen. Ne kuvasivat työpaikkojen odotuksia työterveyshuollon palvelujen suhteen (va 30), yhteistyötä edistäviä ja estäviä tekijöitä (va 33), työpaikkojen kokemuksia työterveyshuollosta (va 43) ja työterveyshuollon palveluihin liittyvää asiakastyytyväisyyttä (va 40). Uusiin toimintatapoibin kuuluivat pienille yrityksille kehitetty työkalu palvelujen tarpeen arviointiin (va 29) sekä mallit sairauspoissaolokäytäntöihin sekä varhaiseen tukeen (va 17). Lisäksi toimintamalleista oli arvioi$t u$ esimiesten näkemyksiä varhaisen tuen mallista (va 38) sekä esimiessoittojen toimivuutta työkykyjohtamisen tukena (va 42).

Työpaikan näkökulmasta tieteellisissä tutkimuksissa tiedonantajina olivat sekä työterveyshuollon (lääkärit, hoitajat, fysioterapeutit, psykologit) että työpaikan edustajat (johto, henki- 
Taulukko 3. Tieteellisten ja vertaisarvioimattomien julkaisujen lukumäärä näkökulmittain ja tutkimusmenetelmittäin. Tutkimusten lukumäärä ja osuudet tieteellisistä tai vertaisarvioimattomista julkaisuista.

\begin{tabular}{|c|c|c|c|}
\hline Julkaisutyyppi & $\begin{array}{l}\text { Määrällinen, } \\
\operatorname{lkm}(\%)\end{array}$ & $\begin{array}{l}\text { Laadullinen, } \\
\text { lkm (\%) }\end{array}$ & $\begin{array}{c}\text { Monimenetelmällinen } \\
\text { (laadullinen ja määrällinen), } \\
\text { lkm (\%) }\end{array}$ \\
\hline \multicolumn{4}{|l|}{ Tieteelliset } \\
\hline Työterveyshuollon näkökulma & $1(8)$ & $5(42)$ & \\
\hline Työpaikan näkökulma & & $1(8)$ & $1(8)$ \\
\hline Työterveysyhteistyö & & $2(17)$ & $2(17)$ \\
\hline Yhteensä & 1 & 8 & 3 \\
\hline \multicolumn{4}{|l|}{ Vertaisarvioimattomat } \\
\hline Työterveyshuollon näkökulma & $1(3)$ & $1(3)$ & $5(16)$ \\
\hline Työpaikan näkökulma & $4(12)$ & $4(13)$ & $2(6)$ \\
\hline Työterveysyhteistyö & $2(6)$ & $8(25)$ & $5(16)$ \\
\hline Yhteensä & 7 & 13 & 12 \\
\hline
\end{tabular}

löstöhallinto, työsuojelu). Vertaisarvioimattomissa tutkimuksissa suurimmassa osassa oli tiedonantajina vain työpaikan edustajia (johto, esimiehet, työsuojelu, työntekijät).

\section{TYÖTERVEYSYHTEISTYÖN TUTKIMUSMENETELMÄT}

Tieteellisiä tutkimuksia työterveyshuollon näkökulmasta oli tehty eniten laadullisilla tutkimusmenetelmillä (Taulukko 3). Monimenetelmällisiä tutkimuksia oli neljännes, näistä yksikään ei edustanut työterveyshuollon näkökulmaa. Pelkästään määrällisellä tutkimusotteella oli tehty yksi tutkimus. Tieteellisissä laadullisissa tutkimuksissa pääasiallisena aineistonkeruumenetelmänä oli haastattelu. Eri aineistoja oli yhdistetty työterveyshuollon ja työterveysyhteistyön näkökulmista olevissa tutkimuksissa. Aineistojen koot ja näkökulmat on ilmoitettu liitteessä. Analyysimenetelminä oli käytetty sisällön-, diskurssi- ja aloiteanalyysiä sekä tilastollisia menetelmiä.

Vertaisarvioimattomissa julkaisuissa tutkimusmenetelmät olivat pääosin monimenetelmällisiä ja laadullisia. Monimenetelmällisistä tutkimuksista suurin osa oli tehty työterveyshuollon tai yhteistyön näkökulmasta. Laadullisista tutkimuksista suurin osa oli yhteistyön näkökulmasta. Määrällisiä tutkimuksia oli vähiten ja niistä suurin osa oli tehty työpaikan näkökulmasta.

Vertaisarvioimattomista laadullisista tutkimuksista yli puolet oli tehty hyödyntäen aineistotriangulaatiota yhdistäen haastattelu- ja dokumenttiaineistoja. Yhdessä tutkimuksessa oli lisäksi käytetty havainnointia. Työpaikan näkökulmasta oli käytetty pelkästään haastatteluaineistoja, jotka oli analysoitu sisällönanalyysillä.
Määrällisissä tutkimuksissa aineistonkeruumenetelmänä olivat kyselyt ja analyysimenetelmänä tilastolliset menetelmät. Vertaisarvioimattomissa monimenetelmällisissä tutkimuksissa oli eniten yhdistetty kyselyjä ja haastatteluja. Näihin oli yhdistetty dokumenttiaineistoa, dokumentti- ja havainnointiaineistoa, tai rekisteri- ja dokumenttiaineistoa. Lähes kaikissa tutkimuksissa analyysimenetelminä oli käytetty sisällönanalyysiä ja tilastollisia menetelmiä. Viidestä julkaisusta ei ilmennyt mitä analyysimenetelmää oli käytetty (va 39-43).

\section{POHDINTA JA JOHTOPÄ̈̈T̈KSET}

\section{TOIMIVAN YHTEISTYÖN MUODOSTUMINEN}

Toimivan työterveysyhteistyön perustana tuli esille sekä toimijoihin että yhteiseen toimintaan liittyviä edellytyksiä. Toimiva työterveysyhteistyö pohjautui työpaikan tarpeisiin, suunnitelmallisuuteen, yhteiseen tavoiteasetantaan sekä yhteiseen seurantaan ja arviointiin. Toimivan työterveysyhteistyön keskiössä oli yhteistyöosaaminen, johon liittyi työpaikan toiminnan tuntemisen lisäksi toimivan yhteistyörakenteen luominen.

Toimivan työterveysyhteistyön tekijät olivat osittain samoja kuin yleiset yhteistyön edellytykset, kuten yhteinen tavoite, luottamus ja sujuva tiedonkulku (44) sekä vuorovaikutuksen säännöllisyys ja toimivat yhteistyörakenteet (6). Kansainvälisessä kirjallisuuskatsauksessa (29) tuli esille samoja edellytyksiä toimivalle yhteistyölle kuin tässä katsauksessa. Kuitenkin suomalaisissa julkaisuissa nousivat vahvemmin esiin yhteiset 
toimintatavat ja sovitut yhteistyökäytänteet ja niissä huomioitiin terveyteen ja henkilöstöjohtamiseen liittyvät osaamistarpeet myös työpaikan näkökulmasta.

Yhteistyötä on luonnehdittu kontekstisidonnaiseksi ilmiöksi (15) ja työterveysyhteistyön kontekstissa painottuvat erityisesti lainsäädäntöön ja muihin yhteiskunnallisiin normeihin liittyvät tekijät. Viime aikoina lainsäädännöllä on pyritty tiivistämään työterveysyhteistyötä, esimerkiksi varhaiseen puuttumiseen $(45,46)$ sekä työterveyshuollon korvauskäytännön uudistamiseen liittyen (47). Yhteistyön on kuvattu perustuvan vapaaehtoisuuteen (8), mutta työterveysyhteistyö ei ole täysin vapaaehtoista. Työterveyshuoltolaki velvoittaa työnantajan järjestämään työterveyshuollon työntekijöilleen, sekä työpaikan ja työterveyshuollon tekemään työterveysyhteistyötä $(26,48)$. Lakien avulla on pyritty luomaan yhteistyörakenteita, mutta ne eivät takaa toimivaa yhteistyötä, sillä yhteistyö syntyy ihmisten välisenä prosessina (15). Työterveyshuollon kannalta yhteistyö on tasapainottelua niin yksittäisen työntekijän terveyden ja työkyvyn, kuin organisaatiotason terveys- ja turvallisuusasioiden huomioimisessa (49). Lisäksi työterveyshuolto on työpaikan ostama palvelu eli työpaikan tarpeiden tulisi määrittää yhteistyö. Tämä tekee työterveysyhteistyöstä kompleksisemman ja monimuotoisemman kuin yhteistyö kahden tasavertaisen toimijan välillä (7).

Yhteistyötä kuvaavien prosessimallien mukaan yhteistyö kehittyy prosessimaisesti väljästä tiiviiseen (16-20). Myös tässä kirjallisuuskatsauksessa yhteistyön tiiviys työpaikan ja työterveyshuollon välillä kuvattiin vaihtelevana. Etäisimmillään yhteistyö koettiin lakisääteisyyden täyttämisenä ja läheisimmillään kumppanuusyhteistyönä. Himmelmanin (20) prosessimallin ensimmäiseen tasoon liittyen toimivassa työterveysyhteistyössä tiedonvaihto nähtiin tärkeänä, koordinoituun tasoon liittyen yhteiset toimintatavat, sekä kolmanteen tasoon liittyen strateginen kumppanuus ja yhteiset tavoitteet. Sen sijaan viimeiseen tasoon liittyvät yhteinen kulttuuri ja yhteinen rakenne eivät tulleet esille tässä kirjallisuuskatsauksessa.

\section{TUTKIMUSTEN KONTEKSTIEN NÄKÖKULMAT JA TIEDONANTAJAT}

Työterveysyhteistyötä oli tutkittu yhteistyön, työterveyshuollon ja työpaikan näkökulmista.
Julkaisuissa käsiteltiin yhteistyökäytäntöjen arviointia, kehittämistä sekä yhteistyön sujuvuutta. Tieteellisiä julkaisuja oli vähän työpaikan näkökulmasta. Tieteellisissä julkaisuissa työterveyshuollon näkökulmasta oli keskitytty työpaikan ja työterveyshuollon väliseen yhteistyöhön. Vertaisarvioimattomissa julkaisuissa yhteistyön kehittäminen liitettiin työterveyshuollon eri prosesseihin, eikä sitä nähty yhteisenä prosessina tai kokonaisuutena työnantajan kanssa. Tulevaisuudessa työterveysyhteistyö tulisi nähdä yhtenäisenä kehittämisen kohteena, jolle asetetaan tavoitteet ja jota arvioidaan yhdessä. Kun yhteistyöstä tulee monimuotoisempaa, voisi sopiva tapa lähestyä yhteistyön kehittämistä olla systeeminen ajattelu (50). Systeemisen ajattelun sisäistämisen kautta voisi työterveyshuolto kehittyä yrityksen strategiseksi kumppaniksi, kun toimintaympäristön moniarvoisuus tunnistetaan ja huomioidaan yrityksen strategiaa muodostettaessa $(51,52)$. Myös kehittävän työntutkimuksen metodologia on soveltunut työterveysyhteistyön tutkimukseen (53). Sekä systeemisessä ajattelussa että kehittävän työntutkimuksen metodologiassa ilmiöt rakentuvat eri osien kokonaisuuksista. Keskeistä kehittävän työntutkimuksessa on historiallinen toimintatapojen analyysi, kun taas systeemisessä ajattelussa ennustaminen ja suunnitelmallisuus $(52,54)$.

Sote-muutos tulee muuttamaan sosiaali- ja terveydenhuollon kenttää ja eri toimijoiden rooleja työikäisten terveydenhuollossa. Työterveyshuolto on tällä hetkellä ainoa linkki työpaikoilta terveydenhuollon palvelujärjestelmään, toisaalta tämä rooli ja työterveysyhteistyön säädöspohja voivat myös muuttua. Tämän vuoksi työterveysyhteistyö ja sen tutkiminen on tärkeää, etenkin kun työterveyshuollon vahvuus on työpaikkojen tunteminen ja työterveysyhteistyö, jota tarvitaan työikäisten yhtenäisen palvelukokonaisuuden rakentamiseen $(2,55)$.

\section{ARVIOINTIA TUTKIMUKSEN TOTEUTTAMISESTA}

Kirjallisuuskatsausta voidaan arvioida seuraavien kriteerien mukaisesti: tutkimuskysymykset ja sisäänottokriteerit, tietojen kerääminen, tietohakujen monipuolisuus, aineiston analyysi ja tutkimusten tieteellinen laatu (56).

Kirjallisuushaut suunniteltiin huolellisesti ja tietokantoihin tehtiin koehakuja luotettavuuden varmistamiseksi (42). Valikoitumisharhaa pyrittiin ehkäisemään laatimalla aineiston sisään- 
ottokriteerit (57). Hakusanat pidettiin yleisinä, koska haluttiin löytää julkaisut, jotka liittyvät sekä työpaikkaan, työterveyshuoltoon että yhteistyöhön. Hakusanoja olisi voinut laajentaa työpaikan näkökulmasta koskemaan esimerkiksi työkyvyn johtamista tai työsuojelua ja näin olisi voinut löytyä enemmän työpaikkaa käsittelevää aineistoa. Jatkotutkimuksissa voisi hakusanoja laajentaa tähän suuntaan.

Tässä katsauksessa käytettiin useita tiedonhaun menetelmiä, jotta kaikki relevantit julkaisut löydettäisiin. Käytännössä kaikkia julkaisuja ei välttämättä löydetty, koska työterveysyhteistyöhön liittyvät julkaisut ovat usein osa työterveyshuollon prosesseihin liittyvää kirjallisuutta. Aineistonhaussa käytettiin myös työterveyshuollon kehittäjien ja tutkijoiden antamia viitteitä, mikä voi johtaa siihen, että aineiston koonti on osittain tehty tiettyjen asiantuntijoiden näkökulmasta (57). Asiantuntijoilta saadut viitteet kuitenkin edustivat kaikkia näkökulmia ja kaikkia aineistoryhmiä.

Aineiston analyysi aloitettiin lukemalla aineisto useaan kertaan läpi ja valitusta aineistosta koottiin systemaattisesti olennaiset tiedot strukturoituun taulukkoon. Aineisto analysoitiin sisältölähtöisesti ja sitä täydennettiin kvantifioinnilla, jotta saatiin esille tyypillisimmät näkemykset ja tutkimustulokset (43).

Aineistoon valittujen julkaisujen raportoinnin tarkkuus vaihteli ja erityisesti aineistojen, analyysimenetelmien ja kohdejoukon kuvaamisessa oli vaihtelua. Julkaisut, joissa oli puutteita aineiston ja menetelmien kuvauksessa on lueteltu tuloksia käsittelevässä kappaleessa. Tähän kirjallisuuskatsaukseen valittiin myös vertaisarvioimattomat julkaisut, koska työterveysyhteistyöstä tehty tieteellinen tutkimus on vähäistä. Tulososiossa on kuvattu erikseen tieteellisten tutkimusten ja vertaisarvioimattomien julkaisujen tulokset, jotta lukija pystyy arvioimaan tulosten luotettavuutta. Alkuperäisten tutkimusten valinnan, laadun arvioinnin, analysoinnin ja tulosten esittämisen suoritti yksi tutkija (SP), jotka vahvisti kaksi tutkijaa $(\mathrm{HH}, \mathrm{JH})$ perehtymällä aineistoon ja keskustelemalla tehdyistä ratkaisuista (38).
Luotettavuutta on pyritty lisäämään selkeällä prosessin kuvauksella kirjallisuushauista tulosten raportointiin saakka, jotta lukija voi arvioida tehtyjä valintoja (58).

\section{JOHTOPÄÄTÖKSET}

Katsaus osoittaa, että 2000-luvulla toimiva työterveysyhteistyö perustuu osin yleisiin yhteistyöhön liittyviin tekijöihin, kuten suunnitelmalliseen toimintaan ja aktiiviseen vuorovaikutukseen. Työterveysyhteistyön kontekstiin liittyy kuitenkin ominaispiirteitä, kuten esimerkiksi yhteistyötä säätelevät lait ja monitasoinen yhteistyö, jotka tekevät yhteistyöstä kompleksisemman. Katsaus kokoaa yhteen, miten ja mistä näkökulmista työterveysyhteistyötä on tutkittu. Katsauksen tuloksia voidaan soveltaa työterveyshuollon kehittämisessä sekä työterveyshuollon tutkimuksen suuntaamisessa. Tieteellisen tutkimuksen vähäinen määrä osoittaa myös, että tarvitaan lisätietoa toimivasta työterveysyhteistyöstä. Koska yhteistyö on ilmiönä ja käsitteenä monimutkainen (6) ja kontekstisidonnainen (15), monimenetelmällinen ja kuvaava laadullinen tutkimus ovat luontevia lähestymistapoja.

\section{KIITOKSET:}

Kiitämme artikkelin kommentoinnista: Halonen Kristiina, työkykyjohtaja Ilmarinen, Laaksonen Maire, ylilääkäri Työterveyslaitos, Österbacka Owe, erityisasiantuntija Työterveyslaitos, Räsänen Kimmo, professori Itä-Suomen yliopisto, Uitti Jukka, professori Tampereen yliopisto ja Salla Atkins, apulaisprofessori, Tampereen yliopisto.

Kirjallisuuskatsaus tehtiin osana ESR:n rahoittamaa Työterveystoiminnan vaikuttavuus ja sen indikaattorit hanketta.

\section{KIRJOITTAJIEN KONTRIBUUTIOT:}

Pesonen, Hakulinen ja Halonen suunnittelivat kirjallisuuskatsauksen. Pesonen toteutti kirjallisuushaut ja analysoi tulokset sekä kirjoitti käsikirjoituksen. Pesonen ja Halonen tulkitsivat tuloksia. Hakulinen ja Halonen kommentoivat käsikirjoitusta aktiivisesti. 
Collaboration in occupational health means collaboration between employers and Occupational Health Service (OHS) providers that is goal-oriented, aims to improve employees' work ability and corresponds to legal requirements. We conducted a literature review of this collaboration between 1/2000 and 9/2017 in Finland. The research questions were: 1) What are constituents of operative collaboration in occupational health? 2) What are the contextual viewpoints that have been considered in this collaboration and who have provided information in these studies? 3) What methods have been used in the study of collaboration in occupational health? This review is descriptive and integrative including scientific (12) and non-scientific (32) articles. 1) Main factors for operative collaboration included operations based on the needs of the em- ployer and long-term relationships between the collaborators. Collaboration should be based on the workplace's strategic plan, have shared goals, and it requires clear roles and active communication. 2) From the OHS providers' viewpoint literature focussed mainly on evaluation of the operations of the OHS. From the employers' viewpoint most research described the expectations and collaboration experiences with the OHS providers. 3) Studies used mainly qualitative or mixed methods. The small number of scientific publications suggests that more research is needed on the constituents of operative collaboration in occupational health.

Keywords: collaboration, occupational health service, work place

\section{LÄHTEET}

(1) Uitti J. Hyvä työterveyshuoltokäytäntö. Saarijärvi: Saarijärvi Offset Oy; 2014.

(2) Työelämäryhmän loppuraportti. Ehdotuksia työurien pidentämiseksi 2010. Luettu 18.3.2019. https://www.etk.fi/wp-content/ uploads/työelämäryhmän_loppuraportti.pdf

(3) Sparks K, Faragher B, Cooper CL. Wellbeing and occupational health in the 21st century workplace. J Occup Organ Psychol 2001;74:489-509. doi:10.1348/096317901167497.

(4) Peckham TK, Baker MG, Camp JE ym. Creating a Future for Occupational Health. Ann Work Expo Health 2017;61:3-15. doi:10.1093/annweh/wxw011.

(5) Husman K, Husman P. Challenges of OHS for Changing Working Life. Int Congr Ser. 2006;1294. doi:10.1016/j.ics.2006.02.061.

(6) Aira A. Toimiva yhteistyö Työelämän vuorovaikutussuhteet, tiimit ja verkostot. Humanistinen tiedekunta: Jyväskylä studies in humanities 179: Jyväskylän yliopisto, 2012.

(7) Lewis LK. Collaborative Interaction: Review of Communication Scholarship and a Research Agenda. Annals of the International Communication Association 2006;30:197-247. doi.org/10.1080/23808985.2006.11679058

(8) Smith KG, Carroll SJ, Ashford SJ. Intra- and Interorganizational Cooperation: Toward a Research Agenda. Academy of Management 1995;38:7-23. doi: $10.2307 / 256726$.

(9) Toiviainen H. Kumppanuus toimintana: Esimerkkinä kahden metalliteollisuuden yrityksen kumppanuusverkosto Helsinki: Työministeriö; 2004.

(10) Eddy PL. Creating strategic partnerships: a guide for educational institutions and their partners. First edition. Sterling, Virginia: Stylus Publishing; 2014.

(11) Dietrich P, Eskerod P, Dalcher D ym. The dynamics of collaboration in multipartner projects. Project Management Journal 2010;41:59-78. doi:10.1002/pmj.20194.

(12) Hibbert P, Huxham, C. Ring, P. Managing Collaborative Inter-organizational Relations. Kirjassa: Cropper S, Huxham, C. Ebers M, Ring P. (toim.) The Oxford Handbook of InterOrganizational Relations: Oxford: Oxford University Press 2010.

(13) Frey L.R. Group communication in context: studies in bona fide groups. 2nd ed. Mahwah, N.J: L. Erlbaum Associates, Publishers; 2003. 
(14) Staples DSC, A. F. Creating positive attitudes in virtual team members. Kirjassa: Godar S.H, Sharmila P.F (toim.) Virtual and collaborative teams: process, technologies and practice. London: Idea Group Inc; 2004, 76-98.

(15) Keyton J, Ford DJ, Smith Fl. A Mesolevel Communicative Model of Collaboration. Communication Theory 2008;18:376-406. doi:10.1111/j.1468-2885.2008.00327.x

(16) Gajda R. Utilizing Collaboration Theory to Evaluate Strategic Alliances. Am J Eval 2004;25:65-77. doi:10.1177/109821400402500105.

(17) Baley D, Koney KM. Startegic alliances among health and human services organization: From affiliations to consolidations. Thousand Oaks: SAGE Publications Inc; 2000.

(18) Hogue T. Community Based Collaboration: Community Wellness Multiplied. Oregon State University: Oregon Center for Community Leadership; 1993.

(19) Peterson N.L. Interagency Collaboration Under Part H: The Key to Comprehensive, Multidisciplinary, Coordinated Infant/ Toddler Intervention Services. J Early Interv 1991;15:89-105. doi:10.1177/105381519101500111.

(20) Himmelman AT. On Coalitions and the Transformation of Power Relations: Collaborative Betterment and Collaborative Empowerment. Am J Community Psychol 2001;29:277-84. doi:10.1023/A:1010334831330.

(21) Noro L. Teollisuushygienian ja työlääketieteen käsikirja. Helsinki: Otava; 1952.

(22) Vaaranen V, Jokinen A, Ylikoski M. Suunnittelu ja tietojärjestelmät. Kirjassa: Rantanen J, Ylikoski M. (toim.) Työterveyshuolto. Jyväskylä: Työterveyslaitos, Gummerus Oy; 1986.

(23) Laki työterveyshuoltolain 2\$:n muuttamisesta 608/1991. https://www.finlex.fi/fi/laki/ alkup/1991/19910608.

(24) Peltomäki P, Husman K. Networking between Occupational Health Services, Client Enterprises and Other Experts: Difficulties, Supporting Factors and Benefits. Int J Occup Med Environ Health. 2002;15: 139-145.

(25) Hallituksen esitys työterveyshuoltolaiksi 114/2001. http://www.finlex.fi/fi/esitykset/ he/2001/20010114.

(26) Valtioneuvoston asetus hyvän työterveyshuoltokäytännön periaatteista, työterveyshuollon sisällöstä sekä ammattihenkilöiden ja asiantuntijoiden koulutuksesta 708/2013. https:/www.finlex.fi/fi/laki/ alkup/2013/20130708.

(27) Schmidt L, Sjostrom J, Antonsson AB. Successful Collaboration between Occupational Health Service Providers and Client Companies: Key Factors. Work. 2015;51:229-237. doi:10.3233/wor-141855.
(28) Juvonen-Posti P, Uitti J, Kurppa K ym. Työterveysyhteistyö. Kirjassa: Uitti J. (toim.) Hyvä työterveyshuolto käytäntö. Saarijärvi: Työterveyslaitos; 2014.

(29). Halonen JI, Atkins S, Hakulinen H ym. Collaboration between employers and occupational health service providers: a systematic review of key characteristics. BMC Public Health. 2017;17:22. doi:10.1186/s12889-016-3924-x.

(30) Ståhl C, Aborg C, Toomingas A ym. The Influence of Social Capital on Employers' Use of Occupational Health Services: A Qualitative Study. BMC Public Health. 2015;15:1083. doi:10.1186/s12889-015-2416-8.

(31) Schmidt L, Sjostrom J, Antonsson AB. How Can Occupational Health Services in Sweden Contribute to Work Ability? Work. 2012;41:2998-3001. doi:10.3233/WOR-2012-0555-2998

(32) Peltomäki P, Husman K. Occupational Health Services and Maintenance of Work Ability at Workplaces. Arh Hig Rada Toksikol. 2002;53: 263-274.

(33) Drift DW. Towards an Effective Co-Operation between Companies and Occupational Safety and Health Services. Int J Occup Med Environ Health. 2002;15: 179-183.

(34) Seuri M, Iloranta K, Räsänen K. Kumppanina työterveyshuolto. Tallinna: Tallinna Raamatutrükikoda; 2011.

(35) Hämäläinen R-M. The Europeanisation of Occupational Health Services: A Study of the Impact of Eu Policies. Kirjassa: Vainio H. (toim.) People and Work Research Reports. Helsinki: Finnish Institute of Occupational Health; 2008.

(36) Evans D. Overview of Methods. Kirjassa: Webb C, Roe B. (toim.) Reviewing Research Evidence for Nursing Practice. Blackwell Publishing Ltd;2008,135-48.

(37) Salminen A. Mikä kirjallisuuskatsaus? Johdatus kirjallisuuskatsauksen tyyppeihin ja hallintotieteellisiin sovelluksiin Vaasa: Vaasan yliopiston julkaisuja;2011.

(38) Whittemore R, Knafl K. The integrative review: updated methodology. J Adv Nurs 2005;52:546-53. doi:10.1111/j.1365-2648.2005.03621.x

(39) Kangasniemi M, Utriainen K, Ahonen S-M ym. Kuvaileva kirjallisuuskatsaus: eteneminen tutkimuskysymyksestä jäsennettyyn tietoon. Hoitotiede 2013;25:291-301.

(40) Grant MJ, Booth A. A typology of reviews: an analysis of 14 review types and associated methodologies. Health Info Libr J 2009;26:91108. doi:10.1111/j.1471-1842.2009.00848.x

(41) Carnwell R, Daly W. Strategies for the construction of a critical review of the literature. Nurse Educ Pract 2001:1:57-63. doi.org/10.1054/nepr.2001.0008. 
(42) Aveyard H. Doing a literature review in health and social care: a practical guide. Maidenhead: Open University Press; 2014.

(43) Fitzgerald SM, Rumrill PD, Jr. Quantitative alternatives to narrative reviews for understanding existing research literature. Work 2005;24:317-323.

(44) Casey M. Partnership - success factors of interorganizational relationships. J Nurs Manag. 2008;16:72-83.

doi:10.1111/j.1365-2934.2007.00771.x.

(45) Laki sairausvakuutuslain muuttamisesta 19/2012. https://www.finlex.fi/fi/laki/ alkup/2012/20120019.

(46) Laki työterveyshuoltolain muuttamisesta 20/2012. https://www.finlex.fi/fi/laki/ alkup/2012/20120020.

(47) Sairasvakuutuslaki 1224/2004. https://www. finlex.fi/fi/laki/ajantasa/2004/20041224\#L13P5.

(48) Työterveyshuoltolaki 1383/2001. https://www.finlex.fi/fi/laki/ ajantasa/2001/20011383.

(49) Heikkinen A. Työterveyshuollon asiakasyritykset odottavat kumppanuusyhteistyöltä merkittävää vaikuttavuutta. Suomen Lääkärilehti. 2007;62:4333-7.

(50) Von Bertalanffy L. The History and Status of General Systems Theory. The Academy of Management Journal. 1972;15:407-426. doi:10.2307/255139.

(51) Halonen K. Pari askelta jäljessä -tuurilla mennään: Tutkimus Suomalaisten organisaatioiden ja työterveyshuollon toteuttamasta henkilöriskienhallinnasta strategisen johtamisen välineenä. Espoo: Aalto-yliopisto, Perustieteiden korkeakoulu,
Tuotantotalouden laitos, Työpsykologia ja johtaminen; 2013.

(52) Whittington R. What is Strategy and does it matter? London: Thomson Learning: 2001.

(53) Rokkanen T. Työterveyshuollon ja työpaikan yhteistyö työpaikan tarpeiden arvioinnissa Helsinki: Työterveyslaitos; 2015.

(54) Engeström Y. Kehittävän työntutkimus: perusteita, tuloksia ja haasteita. Helsinki; Painatuskeskus; 1995.

(55) Viljamaa M, Uitti J, Kurppa K ym. Työterveystoiminnan seurannan indikaattorit -työkyvynhallinnan, seurannan ja varhaisentuen indikaattorit. Helsinki: Työterveyslaitos; 2012.

(56) Shea BJ, Hamel C, Wells GA ym. AMSTAR is a reliable and valid measurement tool to assess the methodological quality of systematic reviews. J Clin Epidemiol 2009;62:1013-1020. doi:10.1016/j.jclinepi.2008.10.009.

(57) Johansson K. Systemaattinen kirjallisuuskatsaus ja sen tekeminen. Turku: Turun yliopisto; 2007.

(58) Rhoades EA. Literature Reviews. Volta Rev 2011;111:353-368.

SANNA Pesonen

TtM, tutkija

Työterveyslaitos

Hanna Hakulinen

TtM, kehittämispäällikkö

Työterveyslaitos

JAANA I HALONEN

FT, erikoistutkija

Työterveyslaitos 
Liitetaulukko. Katsaukseen valitut artikkelit.

\begin{tabular}{|c|c|c|c|}
\hline $\begin{array}{l}\text { viite- } \\
\text { numero }\end{array}$ & Julkaisu & Tutkimusmenetelmä ja aineistot & Näkökulma \\
\hline \multicolumn{4}{|c|}{ Tieteelliset julkaisut $(\mathrm{t} j) \mathrm{n}=12$} \\
\hline tj 1 & $\begin{array}{l}\text { Hakulinen H \& Pirttilä I. } \\
\text { Asiakkuus työterveyshuollon } \\
\text { ja asiakasorganisaatioiden } \\
\text { tulkinnassa. Työelämän } \\
\text { tutkimus } 2012 ; 10(3): 262-80 \text {. }\end{array}$ & $\begin{array}{l}\text { Laadullinen, osallistuva } \\
\text { havainnointi, haastattelu } \\
\text { työterveyshuolto ennen/jälkeen } \\
\mathrm{n}=4 / \mathrm{n}=4 \text {, työpaikka } \mathrm{n}=8 / \\
\mathrm{n}=8 \text {, dokumentit (pöytäkirjat, } \\
\text { muistiinpanot). }\end{array}$ & $\begin{array}{l}\text { Työterveysyhteistyön } \\
\text { näkökulma: asiakkuus }\end{array}$ \\
\hline tj 2 & $\begin{array}{l}\text { Halonen K. Pari askelta } \\
\text { jäljessä -tuurilla mennään. } \\
\text { Väitöskirja. Työpsykologia } \\
\text { ja johtaminen, Aalto } \\
\text { yliopisto, } 2013 .\end{array}$ & $\begin{array}{l}\text { Monimenetelmällinen, } \\
\text { tapaustutkimus: kyselyt } \\
\text { työterveyshuolto } n=59 \text {, työpaikka } \\
\text { johto } n=371 \text {, teemahaastattelu } \\
\text { työpaikka johto } n=8 \text {, dokumentit } \\
\text { (vuosikertomus ja tilinpäätös). }\end{array}$ & $\begin{array}{l}\text { Työpaikan näkökulma: } \\
\text { strateginen kumppanuus }\end{array}$ \\
\hline tj 3 & $\begin{array}{l}\text { Heikkinen, A. } \\
\text { Työterveyshuollon } \\
\text { asiakasyritykset odottavat } \\
\text { kumppanuusyhteistyöltä } \\
\text { merkittävää vaikuttavuutta. } \\
\text { Suomen Lääkärilehti } \\
\text { 2007;62(46):4333-7. }\end{array}$ & $\begin{array}{l}\text { Laadullinen, haastattelut } 4 \text { yritystä, } \\
\text { haastateltavat eri organisaation } \\
\text { tasoilta ja työsuojelusta } n=26 \text {. }\end{array}$ & $\begin{array}{l}\text { Työpaikan näkökulma: } \\
\text { strateginen kumppanuus }\end{array}$ \\
\hline tj 4 & $\begin{array}{l}\text { Janhonen M \& Husman } \\
\text { P. Työterveyshuollot ja } \\
\text { työelämän muutos. Työ ja } \\
\text { ihminen tutkimusraportti } 29 \text {, } \\
\text { Työterveyslaitos, } 2006 \text {. }\end{array}$ & $\begin{array}{l}\text { Määrällinen, Tykybarometri kysely } \\
\text { työterveyshuolto, v. } 1998 \mathrm{n}=1732 \\
\text { ja v. } 2001 \mathrm{n}=2438 \text {, Työ ja Terveys } \\
\text { Suomessa kysely työntekijät } \\
\text { v. } 1997 \mathrm{n}=2156, \text { v. } 2000 \mathrm{n}=2053 \text {, } \\
\text { v. } 2003 \mathrm{n}=2335 \text {; Työterveyshuolto } \\
\text { Suomessa kysely työterveyshuolto } \\
\text { v. } 1995 \mathrm{n}=760 \text {, v. } 1997 \mathrm{n}=880 \text {, } \\
\text { v. } 2000 \mathrm{n}=727 .\end{array}$ & $\begin{array}{l}\text { Työterveyshuollon näkökulma: } \\
\text { toiminnan arviointi }\end{array}$ \\
\hline tj 5 & $\begin{array}{l}\text { Juvonen-Posti P, } \\
\text { Seppänen R, Pesonen S } \\
\text { ym. Työterveysyhteistyö } \\
\text { kuntoutumisen } \\
\text { mahdollistajana. Kuntoutus } \\
\text { 2015;38(3):28-38. }\end{array}$ & $\begin{array}{l}\text { Monimenetelmällinen, kohteena } \\
10 \text { kuntoutujaryhmää, haastattelu } \\
\text { henkilöstöhallinto } n=10 \text {, kyselyt } \\
\text { työterveyshuolto } n=27 \text { ja } n=34 \text {, } \\
\text { ryhmähaastattelu työterveyshuolto } \\
n=5 \text {, asiakirja-aineisto. }\end{array}$ & $\begin{array}{l}\text { Työterveysyhteistyö: } \\
\text { yhteiskäytäntöjen arviointi }\end{array}$ \\
\hline tj 6 & $\begin{array}{l}\text { Rautio M. Muuttuva } \\
\text { työelämä haastaa } \\
\text { työterveyshuollon } \\
\text { kehittämään menetelmiään } \\
\text { ja osaamistaan: } \\
\text { työterveyshuollon } \\
\text { menetelmien kehittäminen } \\
\text { moniammatillisena } \\
\text { oppimisprosessina. } \\
\text { Väitöskirja. Lääketieteellinen } \\
\text { tiedekunta, Oulun yliopisto, } \\
\text { 2004. }\end{array}$ & $\begin{array}{l}\text { Laadullinen, lähtötilanne } \\
\text { kysely työterveyshuolto } n=43 \text {, } \\
\text { prosessikuvaukset, reflektio, } \\
\text { itsearviointi, vertaisarvioinnit: } \\
\text { työterveysyksikkö } n=12 \text {, } \\
\text { asiakasyritykset } n=12 \text {, haastattelu } \\
\text { työpaikan henkilöstöhallinto } n=11 \text {. }\end{array}$ & $\begin{array}{l}\text { Työterveyshuollon näkökulma: } \\
\text { toiminnan arviointi ja uuden } \\
\text { toimintavan kehittäminen }\end{array}$ \\
\hline tj 7 & $\begin{array}{l}\text { Rautio M, Väisänen } \\
\text { A, Mäenpää-Moilanen } \\
\text { E ym. Työyhteisön } \\
\text { toimivuuden edistäminen } \\
\text { työterveyshuollon } \\
\text { toimintana. Työ ja ihminen } \\
\text { Tutkimusraportti } 40, \\
\text { Työterveyslaitos } 2011 \text {. }\end{array}$ & $\begin{array}{l}\text { Laadullinen, työterveysyksikön } \\
\text { kirjalliset prosessikuvaukset } \\
\text { toiminnasta } n=80 \text {, syventävät } \\
\text { haastattelut } n=29 \text {. }\end{array}$ & $\begin{array}{l}\text { Työterveyshuollon näkökulma: } \\
\text { uuden toimintatavan } \\
\text { kehittäminen }\end{array}$ \\
\hline
\end{tabular}




\begin{tabular}{|c|c|c|c|}
\hline tj 8 & $\begin{array}{l}\text { Rokkanen T \& Launis K. } \\
\text { Terveyskeskustyöterveys- } \\
\text { huolto mahdoton tehtävä? } \\
\text { Kaaoksen tunteesta paikal- } \\
\text { lisen toiminnan analyysiin. } \\
\text { Työ ja ihminen tutkimus- } \\
\text { raportti 22, Työterveyslaitos, } \\
2003 \text {. }\end{array}$ & $\begin{array}{l}\text { Laadullinen tapaustutkimus, } \\
\text { interventiokuvaukset } \\
\text { työterveyshuollon työntekijät } n=18 \text {, } \\
\text { haastattelu terveyskeskus johto } n=4 \text {, } \\
\text { työterveyshuollon työntekijöiden } \\
\text { kirjalliset kuvaukset, dokumentit. }\end{array}$ & $\begin{array}{l}\text { Työterveyshuollon näkökulma: } \\
\text { toiminnan arviointi }\end{array}$ \\
\hline tj 9 & $\begin{array}{l}\text { Rokkanen T \& Launis K. } \\
\text { Mitä työterveyshuollon } \\
\text { välineet tavoittavat } \\
\text { pienyrityksessä? I } \\
\text { osa: nykyiset välineet. } \\
\text { Työelämäntutkimus } \\
\text { 2008;6(1):17-29. }\end{array}$ & $\begin{array}{l}\text { Laadullinen tapaustutkimus. } \\
\text { Työterveyshuollon ja } \\
\text { pienyrityksen yhteistyö } \\
\text { dokumentit, työterveyshoitajan } \\
\text { haastattelu, sähköposti-viestit } \\
\text { työterveyslääkärin kanssa. }\end{array}$ & $\begin{array}{l}\text { Työterveyshuollon näkökulma: } \\
\text { toiminnan arviointi }\end{array}$ \\
\hline tj 10 & $\begin{array}{l}\text { Rokkanen T \& Launis K. } \\
\text { Mitä työterveyshuollon } \\
\text { välineet tavoittavat } \\
\text { pienyrityksessä? II osa: } \\
\text { tulevaisuuden välineet. } \\
\text { Työelämäntutkimus } \\
\text { 2008;6(2):147-158. }\end{array}$ & $\begin{array}{l}\text { Laadullinen tapaustutkimus. } \\
\text { Teemahaastattelu työpaikka } n=7 \text {, } \\
\text { dokumentit (yrityksen jäsennykset } \\
\text { toiminnan muuttumisesta). }\end{array}$ & $\begin{array}{l}\text { Työterveyshuollon näkökulma: } \\
\text { uuden toimintatavan } \\
\text { kehittäminen }\end{array}$ \\
\hline tj 11 & $\begin{array}{l}\text { Rokkanen T \& Launis } \\
\text { K. Yhteistyö haasteena } \\
\text {-Analyysi yrityksen } \\
\text { ja työterveyshuollon } \\
\text { sopimusneuvotteluista. } \\
\text { Sosiaalilääketieteellinen } \\
\text { Aikakauslehti } \\
\text { 2005;42(4):327-341. }\end{array}$ & $\begin{array}{l}\text { Laadullinen, dokumentit (lait } \\
\text { ohjeet ja säännöt }(1978-2002)) \\
\text { sekä havainnointi nauhoitetut } \\
\text { sopimusneuvottelutilanteet } n=2 \text {. }\end{array}$ & $\begin{array}{l}\text { Työterveysyhteistyön } \\
\text { näkökulma: yhteistyö- } \\
\text { käytänteiden kehittäminen }\end{array}$ \\
\hline tj 12 & $\begin{array}{l}\text { Seppänen-Järvelä R, Aalto } \\
\text { AM, Juvonen-Posti P ym. } \\
\text { Yksilöllisesti räätälöity ja } \\
\text { työhön kytketty. Sosiaali- ja } \\
\text { terveysturvan tutkimuksia } \\
\text { 139/2015. }\end{array}$ & $\begin{array}{l}\text { Monimenetelmällinen, kysely } \\
\text { työterveyshuolto alku/seuranta } \\
\mathrm{n}=65 / 45 \text {, ryhmähaastattelut } \mathrm{n}=5, \\
\text { kuntoutujakysely } \mathrm{n}=233 / 217, \\
\text { henkilöstöasiantuntijan haastattelu } \\
\mathrm{n}=10 \text {, esimieskysely } \mathrm{n}=101 / 101, \\
\text { työpaikan henkilöstökysely } \\
\mathrm{n}=2211 \text {, henkilöstöasiantuntijan } \\
\text { kysely } \mathrm{n}=25 \text {, } \\
\text { kuntoutuksenpalveluntuottaja } \\
\text { kysely } \mathrm{n}=20 \text {, kuntoutuksen työpajat } \\
\mathrm{n}=10 \text {. }\end{array}$ & $\begin{array}{l}\text { Työterveysyhteistyön } \\
\text { näkökulma: yhteiskäytäntöjen } \\
\text { arviointi }\end{array}$ \\
\hline \multicolumn{4}{|c|}{ Vertaisarvioimattomat julkaisut (va) $n=32$} \\
\hline \multicolumn{4}{|c|}{ Raportit ja selvitykset $\mathrm{n}=17$} \\
\hline va 13 & $\begin{array}{l}\text { Forma P, Harkonmäki K, } \\
\text { Pekka T ym. Kunnallinen } \\
\text { työterveyshuolto } 2008 . \\
\text { Työterveyshuoltojen } \\
\text { organisointi ja } \\
\text { toiminta henkilöstö } \\
\text { asioista vastaavien } \\
\text { ja työterveyshuollon } \\
\text { arvioimana. Kuntien } \\
\text { eläkevakuutuksen raportteja } \\
\text { 4/2008. }\end{array}$ & $\begin{array}{l}\text { Määrällinen, kysely } \\
\text { työterveyshuolto } n=203 \text {, työnantaja } \\
n=333 \text {. }\end{array}$ & $\begin{array}{l}\text { Työterveysyhteistyön } \\
\text { näkökulma: } \\
\text { yhteistyön tekijät }\end{array}$ \\
\hline
\end{tabular}




\begin{tabular}{|c|c|c|c|}
\hline va 14 & $\begin{array}{l}\text { Hakulinen H. Laaksonen } \\
\text { M. Pesonen S. } \\
\text { BotniaSEITTI kunnallinen } \\
\text { työterveyshuolto kehittyy } \\
\text { verkostoissa. Tietoa työstä, } \\
\text { Työterveyslaitos, 2014. }\end{array}$ & $\begin{array}{l}\text { Monimenetelmällinen, } \\
\text { itsearviointikysely } \\
\text { työterveysyksikkö } n=12, \\
\text { työhyvinvointikysely } n=198, \\
\text { laatuavainkysely } n=169, \\
\text { alku/seuranta haastattelu } \\
\text { työterveyshuolto } n=23 / n=11, \\
\text { verkostokysely työterveyshuolto } \\
\mathrm{n}=286 \text {. }\end{array}$ & $\begin{array}{l}\text { Työterveyshuollon näkökulma: } \\
\text { uuden toimintatavan } \\
\text { kehittäminen }\end{array}$ \\
\hline va 15 & $\begin{array}{l}\text { Hakulinen H, Pesonen } \\
\text { S, Laaksonen M ym. } \\
\text { Verkostosta vaikuttavuutta } \\
\text { työterveyshuollon } \\
\text { kehittämiseen SEITTI } \\
\text { alueellisella yhteistyöllä } \\
\text { kohti parempaa } \\
\text { työterveyttä hankkeen } \\
\text { loppuraportti. Tietoa työstä, } \\
\text { Työterveyslaitos, 2012. }\end{array}$ & $\begin{array}{l}\text { Monimenetelmällinen, itsearviointi } \\
\text { kysely työterveyshuolto } n=8 \text {, } \\
\text { teemahaastattelu } n=26 \text {, Laatuavain } \\
\text { kysely } n=74 \text {, työhyvinvointikysely } \\
n=126 \text {, verkostoanalyysi }=138 \text {, } \\
\text { teemahaastattelu kuntapäättäjät } \\
n=17 \text {, asiakastyytyväisyyskysely } \\
\text { hlöasiakkaat n=984, yritykset } \\
n=308 \text {. }\end{array}$ & $\begin{array}{l}\text { Työterveyshuollon näkökulma: } \\
\text { uuden toimintatavan } \\
\text { kehittäminen }\end{array}$ \\
\hline va 16 & $\begin{array}{l}\text { Juntunen P, Puumalainen J, } \\
\text { Mäkelä-Pusa P. Perustuksia } \\
\text { valamassa. Pientyöpaikkojen } \\
\text { työterveysyhteistyö. Punk } \\
\text { hanke. Kuntoutussäätiön } \\
\text { työselosteita, 43/2012. }\end{array}$ & $\begin{array}{l}\text { Monimenetelmällinen, } \\
\text { puolistrukturoitu osallistuva } \\
\text { keskustelu työpaikka n=7, kysely } \\
\text { työpaikka n=139. }\end{array}$ & $\begin{array}{l}\text { Työterveysyhteistyön } \\
\text { näkökulma: yhteistyö- } \\
\text { käytänteiden kehittäminen }\end{array}$ \\
\hline va 17 & $\begin{array}{l}\text { Juvonen-Posti P \& Jalava } \\
\text { J. Lupaavia käytäntöjä pk- } \\
\text { työpaikoille työhyvinvoinnin } \\
\text { ja sairauspoissaolojen } \\
\text { hallintaan ja } \\
\text { seurantaan. Sosiaali- ja } \\
\text { terveysministeriön } \\
\text { selvityksiä 34/2008. } \\
\end{array}$ & $\begin{array}{l}\text { Monimenetelmällinen, } \\
\text { dialogihaastattelut työpaikat, } \\
\text { arviointiseminaari=2, kysely } \\
\text { työpaikka } n=113 \text {. }\end{array}$ & $\begin{array}{l}\text { Työpaikan näkökulma: uuden } \\
\text { toimintatavan kehittäminen }\end{array}$ \\
\hline va 18 & $\begin{array}{l}\text { Juvonen-Posti P, Pesonen } \\
\text { S, Toivio P ym. Työssä } \\
\text { jatkamisen tuki pitkittyvässä } \\
\text { työkyvyttömyydessä. } \\
\text { Arviointitutkimus 1.6.2012 } \\
\text { voimaan astuneiden } \\
\text { työterveyshuoltolain } \\
\text { ja sairasvakuutuslain } \\
\text { muutosten täytäntöönpanon } \\
\text { toteutumisesta. Tietoa } \\
\text { työstä, Työterveyslaitos } \\
\text { 2014. }\end{array}$ & $\begin{array}{l}\text { Monimenetelmällinen, } \\
\text { sairausvakuutusrekisterin } \\
\text { sairauspoissaolot } n=4244, \\
\text { dokumenttilausunnot } n=100, \\
\text { haastattelu työterveyshuolto ja } \\
\text { työpaikka } n=3 \text {. }\end{array}$ & $\begin{array}{l}\text { Työterveysyhteistyön } \\
\text { näkökulma: } \\
\text { yhteistyökäytäntöjen arviointi }\end{array}$ \\
\hline va 19 & $\begin{array}{l}\text { Laine T, Peurala M, } \\
\text { Kemppainen T ym. } \\
\text { Asiakasorganisaatioiden } \\
\text { työterveyshuollon } \\
\text { toimintasuunnitelmien } \\
\text { arviointi ja kehittäminen. } \\
\text { Työterveyslaitos, } \\
\text { Työympäristötutkimuksen } \\
\text { raporttisarja } 42,2009 .\end{array}$ & $\begin{array}{l}\text { Laadullinen, haastattelu työpaikka } \\
\mathrm{n}=17 \text {, tutkimuksen osallistuvien } \\
\text { työpaikkojen työterveyshuolto } \\
\mathrm{n}=22 \text {, } \\
\text { toimintasuunnitelma dokumentit } \\
\mathrm{n}=291 \text {. }\end{array}$ & $\begin{array}{l}\text { Työterveysyhteistyön } \\
\text { näkökulma: } \\
\text { yhteistyökäytäntöjen arviointi }\end{array}$ \\
\hline va 20 & $\begin{array}{l}\text { Leino T, Rautio M, } \\
\text { Kanervisto M ym. } \\
\text { Terveystarkastuskäytännöt } \\
\text { suomalaisessa } \\
\text { työterveyshuollossa. Tietoa } \\
\text { työstä, Työterveyslaitos, } \\
\text { 2014. }\end{array}$ & $\begin{array}{l}\text { Monimenetelmällinen, kysely } \\
\text { työntekijät } n=1150 \text {, dokumentit } \\
\text { (potilasasiakirjat), haastattelu } \\
\text { työterveyslääkäri, työterveyshoitaja } \\
n=8 \text {, työntekijä } n=9 \text {. }\end{array}$ & $\begin{array}{l}\text { Työterveyshuollon näkökulma: } \\
\text { toiminnan arviointi }\end{array}$ \\
\hline
\end{tabular}




\begin{tabular}{|c|c|c|c|}
\hline va 21 & $\begin{array}{l}\text { Palmgren H, Jalonen P. } \\
\text { Kaleva S ym. Vaikuttava } \\
\text { TANO toiminta, } \\
\text { vertailututkimus } \\
\text { työterveyshuollon tietojen } \\
\text { antamisesta, neuvonnasta } \\
\text { ja ohjauksesta (TANO) } \\
\text { asiakasyrityksissä. Tietoa } \\
\text { työstä, Työterveyslaitos, } \\
\text { 2012. }\end{array}$ & $\begin{array}{l}\text { Monimenetelmällinen, kysely } \\
\text { työpaikka n=1322 ja haastattelu } \\
\text { työterveyshuolto } n=192, \\
\text { haastattelu työpaikka } n=192 \text {. }\end{array}$ & $\begin{array}{l}\text { Työterveyshuollon näkökulma: } \\
\text { toiminnan arviointi }\end{array}$ \\
\hline va 22 & $\begin{array}{l}\text { Pekka T \& Forma P. } \\
\text { Työterveysyhteistyö kunta- } \\
\text { alalla vuonna } 2012 \text {. Kevan } \\
\text { tutkimuksia } 1 / 2012 \text {. }\end{array}$ & $\begin{array}{l}\text { Määrällinen, kysely henkilöstöjohto } \\
\text { n=248, kysely työterveyshuolto } \\
\text { johto } n=112 \text {. }\end{array}$ & $\begin{array}{l}\text { Työterveysyhteistyön } \\
\text { näkökulma: yhteistyön tekijät }\end{array}$ \\
\hline va 23 & $\begin{array}{l}\text { Pirttilä I. Miten toimii } \\
\text { terveyskeskusten } \\
\text { työterveyshuolto } \\
\text { suhteessa pienyrityksiin } \\
\text { ja pätkätyöntekijöihin? } \\
\text { Työterveyslaitos, } 2001 \text {. }\end{array}$ & $\begin{array}{l}\text { Laadullinen, tapaustutkimus, } \\
5 \text { työterveysyksikköä, } \\
\text { teemahaastattelu työterveyshuollon } \\
\text { ammattihenkilöt } n=24 \text {, työnantaja } \\
n=21 \text {, työntekijä } n=15 \text {, } \\
\text { terveyskeskuksen johto } n=8 \text {. }\end{array}$ & $\begin{array}{l}\text { Työterveyshuollon näkökulma: } \\
\text { toiminnan arviointi }\end{array}$ \\
\hline va 24 & $\begin{array}{l}\text { Pulkkinen-Närhi P, } \\
\text { Hakulinen H, Jalonen } \\
\text { P ym. Kunnallisen } \\
\text { työterveyshuoltojärjestelmän } \\
\text { kehittäminen. Erilaisten } \\
\text { organisointi- ja } \\
\text { toimintamallien arviointia } \\
\text { (SEUTU-hanke). Sosiaali- } \\
\text { ja terveysministeriön } \\
\text { selvityksiä 3/2008. }\end{array}$ & $\begin{array}{l}\text { Monimenetelmällinen, ITE } \\
\text { kysely työterveyshuolto } \\
\text { alku/seuranta } n=30 / n=20, \\
\text { työnkuormituskysely } n=36 / n=26 \text {, } \\
\text { kysely toimintasuunnitelmat/ } \\
\text { kertomukset } n=9 \text {, haastattelut } n=6 / \\
n=6 \text {, asiakastyytyväisyyskysely } \\
\text { alku/seuranta hlöasiakkaat } n=2968 \text { / } \\
n=2077 \text {, yritysasiakkaat } n=592 / \\
n=381 \text {. }\end{array}$ & $\begin{array}{l}\text { Työterveyshuollon näkökulma: } \\
\text { toiminnan arviointi }\end{array}$ \\
\hline va 25 & $\begin{array}{l}\text { Savinainen M, Mattila } \\
\text { S, Merivirta M-L } \\
\text { ym. Riskinarviointi } \\
\text { ja työpaikkaselvitys - } \\
\text { pienten työpaikkojen ja } \\
\text { työterveyshuollon yhteistyön } \\
\text { tuloksena. Tietoa työstä, } \\
\text { Työterveyslaitos, 2014. }\end{array}$ & $\begin{array}{l}\text { Monimenetelmällinen, } \\
\text { käytettävyyskysely työterveyshuolto } \\
n=27 \text {, työpaikka henkilöstökysely } \\
n=69 \text {, ryhmähaastattelu } \\
\text { työterveyshuolto } n=21 \text {, työpaikka } \\
n=20 \text {. }\end{array}$ & $\begin{array}{l}\text { Työterveysyhteistyön } \\
\text { näkökulma: } \\
\text { yhteistyökäytäntöjen arviointi }\end{array}$ \\
\hline va 26 & $\begin{array}{l}\text { Savinainen M, Peurala M, } \\
\text { Manninen P ym. } \\
\text { Työterveyshuollon } \\
\text { työpaikkaselvitys osana } \\
\text { yritysten hyvinvointi- ja } \\
\text { turvallisuustoimintaa. } \\
\text { Työympäristö-tutkimuksen } \\
\text { raporttisarja 55, } \\
\text { Työterveyslaitos, } 2011 \text {. }\end{array}$ & $\begin{array}{l}\text { Monimenetelmällinen, kysely } \\
\text { työterveyshuolto } n=1058 \text {, } \\
\text { ryhmähaastattelut työterveyshuolto } \\
\text { ja työpaikka } n=13 \text {. }\end{array}$ & $\begin{array}{l}\text { Työterveysyhteistyön } \\
\text { näkökulma: } \\
\text { yhteistyökäytänteiden } \\
\text { kehittäminen }\end{array}$ \\
\hline va 27 & $\begin{array}{l}\text { Siljanen E-M, Rautio } \\
\text { M, Husman P. Terveyttä } \\
\text { ja hyvinvointia yhdessä } \\
\text { kehittämällä. (TEDI } \\
\text { hanke). Tietoa työstä, } \\
\text { Työterveyslaitos 2012. }\end{array}$ & $\begin{array}{l}\text { Laadullinen, prosessin aikana } \\
\text { muodostunut aineisto (kriteerit, } \\
\text { kehittämissuunnitelmat, } \\
\text { arviointipalaverien yhteenvedot), } \\
\text { dokumenttiaineisto, haastattelu } \\
\text { työterveyshuolto } n=2 \text {, työpaikka } \\
\mathrm{n}=8 \text {. }\end{array}$ & $\begin{array}{l}\text { Työterveysyhteistyön } \\
\text { näkökulma: } \\
\text { yhteistyökäytänteiden } \\
\text { kehittäminen }\end{array}$ \\
\hline
\end{tabular}




\begin{tabular}{|c|c|c|c|}
\hline va 28 & $\begin{array}{l}\text { Viljamaa M, Uitti J, Kurppa } \\
\text { K ym. Työterveystoiminnan } \\
\text { seurannan indikaattorit } \\
\text {-työkyvynhallinnan, } \\
\text { seurannan ja varhaisentuen } \\
\text { indikaattorit. Tietoa työstä, } \\
\text { Työterveyslaitos, 2012. }\end{array}$ & $\begin{array}{l}\text { Laadullinen, haastattelu työpaikka } \\
\text { ja työterveyshuolto } n=19 \text {, } \\
\text { työpaikkojen dokumentit (työkyvyn } \\
\text { tuki malli, toimintasuunnitelma, } \\
\text { työsuojelun toimintaohjelma). }\end{array}$ & $\begin{array}{l}\text { Työterveysyhteistyön } \\
\text { näkökulma: vaikuttavuus ja } \\
\text { laatu }\end{array}$ \\
\hline va 29 & $\begin{array}{l}\text { Virokannas H \& Pyrrö } \\
\text { P. Pienen yrityksen omien } \\
\text { työterveyspalvelujen } \\
\text { tarpeen arviointi ja } \\
\text { hankinta. Kehityshankkeen } \\
\text { loppuraportti. } \\
\text { Työterveysverkko, } 2010 .\end{array}$ & $\begin{array}{l}\text { Monimenetelmällinen, neljän } \\
\text { työpaikan tapaustutkimus, kysely } \\
\text { työpaikka } n=131 \text {, haastattelu } \\
\text { työpaikka } n=4 \text {. }\end{array}$ & $\begin{array}{l}\text { Työpaikan näkökulma: uuden } \\
\text { toimintatavan kehittäminen }\end{array}$ \\
\hline \multicolumn{4}{|c|}{ Opinnäytetyöt n=9 } \\
\hline va 30 & $\begin{array}{l}\text { Antila T. } \\
\text { Asiakkuudenhallinnan } \\
\text { kehittäminen työterveydessä. } \\
\text { Opinnäyte, Ylempi AMK, } \\
\text { Tampereen Ammattikorkea- } \\
\text { koulu, 2013. }\end{array}$ & $\begin{array}{l}\text { Määrällinen, tapaustutkimus, } \\
\text { työpaikan esimiehet } n=36 \text {. }\end{array}$ & $\begin{array}{l}\text { Työpaikan näkökulma: } \\
\text { asiakkuus }\end{array}$ \\
\hline va 31 & $\begin{array}{l}\text { Hakala L. Yritys ja } \\
\text { työterveyshuolto. Pro gradu, } \\
\text { sosiologian laitos, Turun } \\
\text { yliopisto, 2005. }\end{array}$ & $\begin{array}{l}\text { Laadullinen, haastattelut työpaikan } \\
\text { edustajat } n=10 \text {. }\end{array}$ & $\begin{array}{l}\text { Työpaikan näkökulma: } \\
\text { strateginen kumppanuus }\end{array}$ \\
\hline va 32 & $\begin{array}{l}\text { Koskela L. Palvelukyky, } \\
\text { palveluhalu, ammattitaito, } \\
\text { niistähän se tulee. Pro } \\
\text { gradu, terveystieteen laitos, } \\
\text { Tampereen yliopisto } 2011 .\end{array}$ & $\begin{array}{l}\text { Monimenetelmällinen, kysely } \\
\text { työterveyshuolto } n=62 \text {, haastattelu } \\
\text { työpaikka } n=16 \text {. }\end{array}$ & $\begin{array}{l}\text { Työterveysyhteistyön } \\
\text { näkökulma: asiakkuus }\end{array}$ \\
\hline va 33 & $\begin{array}{l}\text { Laulumaa A-M. } \\
\text { Työterveyshuollon ja } \\
\text { asiakasyrityksen yhteistyö: } \\
\text { yrityksen esimiehen } \\
\text { näkökulma. Pro gradu, } \\
\text { hoitotieteen laitos, Turun } \\
\text { yliopisto, 2010. }\end{array}$ & $\begin{array}{l}\text { Laadullinen, haastattelu työpaikka } \\
\mathrm{n}=22 \text {. }\end{array}$ & $\begin{array}{l}\text { Työpaikan näkökulma: } \\
\text { asiakkuus }\end{array}$ \\
\hline va 34 & $\begin{array}{l}\text { Lautala K. } \\
\text { Metalliteollisuuden } \\
\text { pienyritysten ja } \\
\text { työterveyshuollon } \\
\text { yhteistyö. Luottamus ja } \\
\text { sosiaalinen pääoma. Pro } \\
\text { gradu, sosiaalipolitiikka, } \\
\text { Tampereen yliopisto, 2016. }\end{array}$ & $\begin{array}{l}\text { Laadullinen, haastattelu työpaikka } \\
\mathrm{n}=6 \text {, haastattelu asiantuntijat } \mathrm{n}=2 \text {. }\end{array}$ & $\begin{array}{l}\text { Työpaikan näkökulma: } \\
\text { strateginen kumppanuus }\end{array}$ \\
\hline va 35 & $\begin{array}{l}\text { Lindell M. } \\
\text { Työterveyshuollon ja } \\
\text { työsuojelun yhteistyö - } \\
\text { Työterveyshuoltotiimien } \\
\text { ja työsuojelutoimijoiden } \\
\text { käsitykset yhteistyöstä. Pro } \\
\text { gradu, hoitotieteen laitos, } \\
\text { Turun yliopisto, 2014. }\end{array}$ & $\begin{array}{l}\text { Laadullinen, focus group } \\
\text { haastattelu työterveyshuolto } n=7 \text {, } \\
\text { työpaikka } n=12 \text {. }\end{array}$ & $\begin{array}{l}\text { Työterveysyhteistyön } \\
\text { näkökulma: } \\
\text { yhteistyön tekijät }\end{array}$ \\
\hline va 36 & $\begin{array}{l}\text { Lindell R. Hoitotyön } \\
\text { johtajien ja } \\
\text { työterveyshuollon yhteistyö } \\
\text { henkilöstön työhyvinvoinnin } \\
\text { edistämisessä. Pro gradu } \\
\text { Hoitotieteenlaitos, Kuopion } \\
\text { yliopisto, 2007. }\end{array}$ & $\begin{array}{l}\text { Laadullinen, teemahaastattelut } \\
\text { työterveyshuolto } n=4 \text {, työpaikka } \\
n=11 \text {. }\end{array}$ & $\begin{array}{l}\text { Työterveysyhteistyön } \\
\text { näkökulma: } \\
\text { yhteistyön tekijät }\end{array}$ \\
\hline
\end{tabular}




\begin{tabular}{|c|c|c|c|}
\hline va 37 & $\begin{array}{l}\text { Luomala T. Asiakasyrityksen } \\
\text { ja työterveyshuollon } \\
\text { välinen yhteistyö. TEROKA } \\
\text { hankkeeseen osallistuneiden } \\
\text { näkemyksiä. } \\
\text { Pro gradu, terveystieteiden } \\
\text { laitos, Jyväskylän yliopisto, } \\
\text { 2013. }\end{array}$ & $\begin{array}{l}\text { Laadullinen, teemahaastattelut } \\
\text { työterveyshuolto } n=4 \text {, työpaikka } \\
n=7 \text {. }\end{array}$ & $\begin{array}{l}\text { Työterveysyhteistyön } \\
\text { näkökulma: yhteistyön tekijät }\end{array}$ \\
\hline va 38 & $\begin{array}{l}\text { Runola E-K. Varhaisentuen } \\
\text { toimintamalli ja työterveys- } \\
\text { yhteistyö. Pro gradu, } \\
\text { hoitotiede, Turun yliopisto, } \\
\text { 2014. }\end{array}$ & $\begin{array}{l}\text { Määrällinen, kysely työpaikka } \\
n=164 \text {, työterveyshuolto } n=15 \text {. }\end{array}$ & $\begin{array}{l}\text { Työpaikan näkökulma: } \\
\text { toimintamallin arviointi }\end{array}$ \\
\hline \multicolumn{4}{|c|}{ Ammattilehti artikkelit $n=6$} \\
\hline va 39 & $\begin{array}{l}\text { Hakulinen } \mathrm{H} \text {. Asiakassuhde } \\
\text { yhteistyön siltana. } \\
\text { Työterveyshoitaja, } \\
\text { 2009;34(2):16-17. }\end{array}$ & $\begin{array}{l}\text { Laadullinen, havainnointi, } \\
\text { teemahaastattelut, asiakirjat. }\end{array}$ & $\begin{array}{l}\text { Työterveysyhteistyön } \\
\text { näkökulma: asiakkkuus }\end{array}$ \\
\hline va 40 & $\begin{array}{l}\text { Hakulinen H \& } \\
\text { Kantola M. Kunnallisen } \\
\text { työterveyshuollon } \\
\text { asiakastyytyväisyys } \\
\text { henkilö- ja yritysasiakkaiden } \\
\text { arvioimana. } \\
\text { Työterveyshoitaja } \\
\text { 2011;36(1):18-19. }\end{array}$ & $\begin{array}{l}\text { Määrällinen, } \\
\text { asiakastyytyväisyyskysely, } \\
\text { henkilöasiakkaat } n=1016, \\
\text { yritysasiakkaat } n=329 .\end{array}$ & $\begin{array}{l}\text { Työpaikan näkökulma: } \\
\text { asiakkuus }\end{array}$ \\
\hline va 41 & $\begin{array}{l}\text { Heikkinen A \& Pasternack } \\
\text { I. Onko meillä yhteiset } \\
\text { arvot? Haastattelututkimus } \\
\text { yritysten ja } \\
\text { työterveyshuollon } \\
\text { käsityksistä } \\
\text { yhteistyön perustasta. } \\
\text { Työterveyslääkäri } \\
\text { 2008;26(4): } 27-29 \text {. }\end{array}$ & $\begin{array}{l}\text { Laadullinen, haastattelu työpaikka } \\
\text { ja työterveyshuolto } n=37 \text {. }\end{array}$ & $\begin{array}{l}\text { Työterveysyhteistyön } \\
\text { näkökulma: yhteistyön tekijät }\end{array}$ \\
\hline va 42 & $\begin{array}{l}\text { Kotronen A, Nopola- } \\
\text { Pärssinen R, Vanni P ym. } \\
\text { Esimiessoitot tiivistävät } \\
\text { työterveyden ja työpaikan } \\
\text { yhteistyötä - uusi } \\
\text { toimintatapa tukemaan } \\
\text { työkykyjohtamista. } \\
\text { Työterveyslääkäri } \\
\text { 2014;32(1): 58-61. }\end{array}$ & $\begin{array}{l}\text { Laadullinen, haastattelu työpaikka } \\
\mathrm{n}=81 \text {. }\end{array}$ & $\begin{array}{l}\text { Työpaikan näkökulma: } \\
\text { toimintamallin arviointi }\end{array}$ \\
\hline va 43 & $\begin{array}{l}\text { Pakkala L, Kalanen K } \\
\text { ym. Yrittäjät eivät tunne } \\
\text { työterveyshuollon toimintaa } \\
\text {-syy yrittäjien vähäiseen } \\
\text { työterveyshuollon käyttöön? } \\
\text { Työterveyslääkäri 2004;(2): } \\
255-229 \text {. }\end{array}$ & Määrällinen, kysely yrittäjät n=149. & $\begin{array}{l}\text { Työpaikan näkökulma: } \\
\text { asiakkuus }\end{array}$ \\
\hline va 44 & $\begin{array}{l}\text { Rantanen S, Pääkkönen } \\
\text { R, Jokitulppo J ym. Kysely } \\
\text { työpaikkaselvityksistä } \\
\text { ja riskinarvioinnista. } \\
\text { Työterveyslääkäri 2003;(2): } \\
\text { 223-230. }\end{array}$ & $\begin{array}{l}\text { Määrällinen, kysely } \\
\text { työterveyshuolto } n=158 \text {. }\end{array}$ & $\begin{array}{l}\text { Työterveyshuollon näkökulma: } \\
\text { toiminnan arviointi }\end{array}$ \\
\hline
\end{tabular}

